Bernard Bourreli MD, Michel Pinaud MD, Norbert Passuti MD, Jcan-Pierrc Gunst MD, Jean-Christophe Drouet MD, Jean-Pierre Remi mD

\title{
Additive effects of dihydralazine during enflurane or isoflurane hypotensive anaesthesia for spinal fusion
}

Sixleen patients ( $13-38$ yr) undergoing spinal fusion for scoliosis under controlled hypotension were studied to determine the haemodynamic and neuroendocrine responses to IV dihydrala. zine $\left(1.0 \mathrm{mg} \cdot \mathrm{kg}^{-1}\right)$ followed by 0.5 and I MAC of enflurane or isoflurane. Twenty minutes after dihydralozine administration mean arterial pressure (-20 per cent) and systemic vascular resistance ( -50 per cent) decreased, and cardiac index ( +57 per cent), heart rate $(+37$ per cent) and intrapulmonary shunt increased. Plasma renin activity and aldosterone and norepinephrine levels increased. Further decreases in mean arrerial pressure and in systemic vascular resistance were observed when 0.5 MAC enflurane or isoflurane were added. With $1 \mathrm{MAC}$ anaesthetic levels a further decrease in mean arterial pressure was observed in both goups, but pressure fell to a lower level with isoflurane than with enflurane ( $p<0.01$ ). The reduction of arterial blood pressure to a level of $50-60 \mathrm{mmHg}$ for three to four hours was easy to control and was free of complications. The preliminary IV administration of dihydralazine allowed a reduced volatile agent concentration which attenuated undesirable haemodynamic effects, in spite of renin and norepinephrine release, and permitted a rapid intraoperative awaken. ing.

\section{Key words}

ANAESTHETICS, VOLATILE: enflurane, isoflurane; ANAESTHETIC TECHNIQUES: hypotensive, dihydralazine; POLYPEPTIDES: renin-angiotensin; SURGERY: orthopaedic, spinal fusion; SYMPATHETIC NERYOUS SYSTEM: catecholamine.

From the Département d'Anesthésiologie, Clinique Orthopédique et Service de Médecine Nucléaire (JPR), Centre Hospitalier Universitaire, Nantes, France.

Address correspondence to: Docteur B. Bourreli, Département d'Anesthésie et de Réanimation Chirurgicale, Hôtel-Dieu, C.H.L., 44035 Nantes Cédex D1, France.

This work was supported in part by the University of Nantes Institutional Grants Program.
Induced hypotension has been established as a means of reducing blood loss and improving operating conditions during spinal fusion for scoliosis. ${ }^{1-3}$ The choice of the technique and the ideal level of arterial blood pressure remain controversial, especially when hypotension is needed for a prolonged period of time. However, the mean blood pressure should not be reduced to less than $50-60 \mathrm{mmHg}$ in normotensive patients. ${ }^{4}$ The agents most frequently used produce hypotension by pharmacological alterations of vascular resistance and/or cardiac output. The method employed by James and Bedford in neurosurgery, a combination of a direct vasodilator (hydralazine) and an inhalation anaesthetic (enflurane), permits a stable level of hypotension to be achieved, without rebound hypertension. ${ }^{5}$ The low inspired concentration of enflurane used by these authors is attractive in order to allow rapid intraoperative awakening during scoliosis surgery. ${ }^{6-8}$ Isoflurane's physical and haemodynamic properties of marked systemic vasodilation, minimal cardiac depression and rapid elimination ${ }^{9}$ justify the evaluation of this agent for inducing deliberate hypotension during scoliosis surgery.

The aims of this study involving only healthy young adults were: (1) to determine the haemodynamic responses to IV dihydralazine during opiate anaesthesia; (2) to compare the haemodynamic responses to 0.5 and 1 MAC of enflurance and isoflurane following IV dihydralazine to induce hypotension; (3) to determine the neuroendocrine effects of dihydralazine and the dihydralazine-isoflurane combination.

\section{Methods}

The study was approved by the committee on human studies of our University hospital. Informed consent was obtained from each patient or an appropriate relative. Sixteen patients (eight females, eight males) mean age $19.3 \mathrm{yr}(13$ to $38 \mathrm{yr}$ ) who required spinal fusion with Harrington instrumentation for scoliosis were studied. All had a negative history and physical examination for cardiovascular and renal diseases, and routine laboratory 
tests were within normal limits. Patients were premedicated with diazepam $\left(0.2 \mathrm{mg} \cdot \mathrm{kg}^{-1}\right)$ PO 90 min before induction of anaesthesia. No atropine nor similar drug were used. Induction was with thiopentone $\left(7.0 \mathrm{mg} \cdot \mathrm{kg}^{-1}\right)$ and fentanyl $\left(5.0 \mu \mathrm{g} \cdot \mathrm{kg}^{-1}\right)$. Pancuronim $\left(0.1 \mathrm{mg} \cdot \mathrm{kg}^{-1}\right)$ was used to facilitate tracheal intubation. Ventilation with nitrous oxide in oxygen $\left(\mathrm{FIO}_{2}: 0.5\right)$ was controlled to maintain arterial blood carbon dioxide tension $\left(\mathrm{PaCO}_{2}\right)$ between 4 and $4.8 \mathrm{kPa}$. Analgesia was maintained with fentanyl $\left(3 \mu \mathrm{g} \cdot \mathrm{kg}^{-1} \cdot \mathrm{hr}^{-1}\right)$ which was stopped one hour before the expected time of intraoperative awakening in patients without neurologic disease. Urine was collected from an indwelling catheter.

Heart rate was monitored by a VS ECG lead. An indwelling teflon cannula was inserted into a non-cominant radial artery for systolic (SAP) and diastolic blood pressure (DAP) measurements and for blood samples. A 7-F triple lumen thermodilution Swan Ganz catheter (standard $93 \mathrm{~A} 131 \mathrm{H}$ or small anatomy $93 \mathrm{~A} 140$ ) was inserted into the right internal jugular vein under fluoroscopic control to measure right atrial pressure (RAP), systolic (SPAP) and diastolic (DPAP) pulmonary arterial pressures, pulmonary capillary wedge pressure (PCWP) and cardiac output (CO) (iced injectate in triplicatc). All pressures were referenced to the level of the right atrium. $\mathrm{HR}$ and pressures were recorded simultaneously on a polygraph. Derived haenodynamic values were calculated in the usual manner ${ }^{10}$ : mean arterial pressure (MAP), cardiac index (CI), stroke index (SI), systemic vascular resistance index (SVRI), pulmonary yascular resistance index (PVRI), $\mathrm{PO}_{2}, \mathrm{pH}, \mathrm{PCO}_{2},(\mathrm{ABL} 30$ acid-base analyzer Radiometer), $\mathrm{SO}_{2}$, and haemoglobin concentration (OSM2 Hemoximeter Radiometer) were measured in arterial blood and in mixed venous blood. The arterial $\left(\mathrm{CaO}_{2}\right)$, mixed venous $\left(\mathrm{CrO}_{2}\right)$ and pulmonary capillary $\left(\mathrm{CcO}_{2}\right)$ oxygen contents, the intrapulmonary shunt $(\mathrm{Q} / \mathrm{Qt})$

TABLE 1 Study group characteristics (mean \pm SD)

\begin{tabular}{|c|c|c|}
\hline & $\begin{array}{l}\text { Enfurane } \\
n=8\end{array}$ & $\begin{array}{l}\text { Isofurane } \\
n=8\end{array}$ \\
\hline Age $(y r)$ & $18.6 \pm 5.8$ & $20.1 \pm 8.2$ \\
\hline Weight (kg) & $48.1 \pm 9.6$ & $53.1 \pm 10.2$ \\
\hline $\operatorname{Sex}$ & $5 \mathrm{M} ; 3 \mathrm{~F}$ & $3 \mathbf{M} ; 5 \mathrm{~F}$ \\
\hline \multicolumn{3}{|l|}{ Aetiology of scoliosis } \\
\hline neurologic disesse & 2 & 3 \\
\hline idiopathic & 6 & 5 \\
\hline Awakening delay (min) ${ }^{*}$ & $6.4 \pm 3.5$ & $5.5 \pm 3.0$ \\
\hline Peroperative fluid volume (mi) & $2000 \pm 1100$ & $2150 \pm 1200$ \\
\hline Duration of operation (min) & $244 \pm 52$ & $226 \pm 44$ \\
\hline $\begin{array}{l}\text { Postoperative fluid volume } \\
\text { during first } 24 \text { hours (m) }\end{array}$ & $1500 \pm 450$ & $1350 \pm 375$ \\
\hline
\end{tabular}

$p=$ NS.

*Intraoperative awakening was not performed in neurologic patients.
TABLE II Effects of IV dihydralazine (1.0 mg $\left.\cdot \mathrm{kg}^{-1}\right)$ during stable anuesthesia $(n=16$; mean \pm SD)

\begin{tabular}{|c|c|c|c|}
\hline & Control & Dihydralazine & $p$ value \\
\hline SAP (mmHg) & $117 \pm 8$ & $102 \pm 10$ & $<0.001$ \\
\hline DAP (mmHg) & $80 \pm 7$ & $62 \pm 6$ & $<0.001$ \\
\hline $\operatorname{MAP}(\mathrm{mmH})$ & $95 \pm 8$ & $76 \pm ?$ & $<0.001$ \\
\hline HR (beats-min ${ }^{-1}$ ) & $87 \pm 7$ & $119 \pm 8$ & $<0.001$ \\
\hline MPAP (mmHg) & $16.3 \pm 2.7$ & $17.3=3.6$ & NS \\
\hline PCWP (mIHg) & $8.2 \pm 2.1$ & $8.7 \pm 2.9$ & NS \\
\hline $\mathrm{Cl}\left(\mathrm{L} \cdot \mathrm{min}^{-1} \cdot \mathrm{m}^{-2}\right)$ & $3.50 \pm 0.35$ & $5.50=0.80$ & $<0,001$ \\
\hline $\mathrm{SI}\left(\mathrm{ml} \cdot\right.$ beat $\left.^{-1} \cdot \mathrm{m}^{-2}\right)$ & $40 \pm 5$ & $46 \pm 5$ & $<0,05$ \\
\hline SVRI $\left(\mathrm{d} \gamma \mathrm{n} \cdot \mathrm{s} \cdot \mathrm{cm}^{-5} \cdot \mathrm{m}^{-2}\right)$ & $2050 \pm 200$ & $995=155$ & $<0.001$ \\
\hline $\mathrm{CaO}_{2}\left(\mathrm{ml} \mathrm{O}_{2} \cdot \mathrm{dt}^{-1}\right)$ & $16.4 \pm 1.5$ & $17.1 \pm 1.5$ & NS \\
\hline $\mathrm{CrO}_{2}\left(\mathrm{mll} \mathrm{O}_{2} \cdot \mathrm{dl}^{-}\right)$ & $12.9 \pm 1.4$ & $15.0 \pm 1.5$ & $<0.01$ \\
\hline$Q_{s} / Q t(\varphi)$ & $8.4 \pm 3.7$ & $13.7 \pm 6.1$ & $<0.01$ \\
\hline $\mathrm{VO}_{2} 1\left(\mathrm{ml} \mathrm{O} \mathrm{O}_{2} \cdot \mathrm{min}^{-1} \cdot \mathrm{m}^{-2}\right)$ & $112 \pm 21$ & $117 \pm 17$ & NS \\
\hline
\end{tabular}

and the whole body oxygen consumption $\left(\mathrm{VO}_{2}\right)$ were calculated.

Arterial blood samples were drawn for determination of plasma renin activity (PRA), aldosterone and catecholamine levels. Blood samples were immediately centrifuged at $4^{\circ} \mathrm{C}$ for $10 \mathrm{~min}$ at $3000 \mathrm{rpm}$ and plasma was stored at $-80^{\circ} \mathrm{C}$ until subsequent analysis. PRA was measured using the method of Haber et al. "with an angiotensin I radioimmunoassay kit (SB-REN-1 CEA SORIN). Aldosterone was measured using an aldosterone radioimmunoassay kit (SB-Aldo-H, CEA SORIN) by the method of Mayes et al. ${ }^{12}$ Norepinephrine (NE) and epinephrine (E) plasma concentrations were measured, according to Brown and Jenner, ${ }^{13}$ with a double-isotope enzymatic assay with a sensitivity of $1.5 \mathrm{pg} \cdot \mathrm{ml}^{-1}$ for both $\mathrm{E}$ and NE. The coefficients of variations were 3.1 and 3.3 per cent for $\mathrm{NE}$ and $\mathrm{E}$ respectively (intraassay) and 4.2 and 4.5 per cent (interassay) in our laboratory. ${ }^{14}$

Surgery was performed with the patients in the prone position on the Relton Hall frame in order to reduce pressure on the abdomen. Hypotersion was initiated 20 minutes before skin incision, with an IV injection of dihydralazine (Nepressol Ciba Geigy) ( ${ }^{\circledR} .0 \mathrm{mg} \cdot \mathrm{kg}^{-1}$ ). Patients were then randomly assigned to two groups: enflurane (Group 1) or isoflurane (Group 2). The inhalation anaesthetic was started at the time of the skin incision and inspired concentrations were adjusted to achieve end-tidal concentrations of 0.5 MAC 0.85 vol\% for enflurane and 0.65 vol\% for isoflurane), and 1 MAC ( 1.7 vol\% for enflurane and 1.3 vol\% for isoflurane). Onehalf the patients received the $0.5 \mathrm{MAC}$ level first and the other one-half 1 MAC first. End-tidal anaesthetic concentration was monitored by an infrared analyzer (Normac ${ }^{\oplus}$ Datex). A second IV injection of dihydralazine $\left(0.25 \mathrm{mg} \cdot \mathrm{kg}^{-1}\right)$ was administered if necessary 1.30 to $2 \mathrm{hr}$ after the first injection to maintain hypotension in con- 


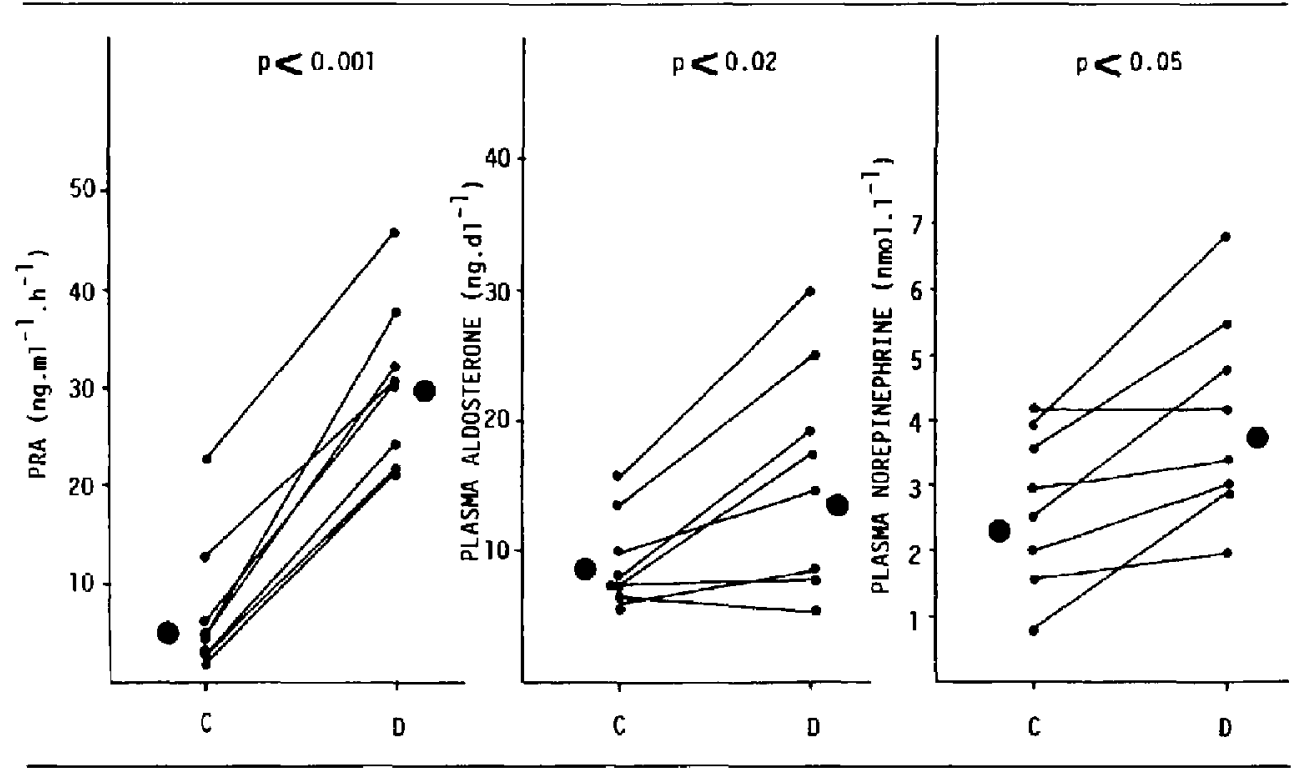

FIGURE Plasma renin activity, plasma aldosterone, and plasma norepinephrine concentrations before $(C)$ and 20 min after IV injection of dihydralazine $\left(1.0 \mathrm{mg}^{\prime} \mathrm{kg}^{-1}\right)$ (D). Individual values $(\longrightarrow)$ and mean values $\$$

junction with low doses of isoflurane or enflurane. Haemodynamic data were collected 10 min after positioning the patient in the prone position before first dihydralazine injection (control: $\mathrm{C}$ ), $20 \mathrm{~min}$ after first dihydralazine injection just before skin incision (dihydralazine: D) and during the surgical procedure $20 \mathrm{~min}$ after each vapour setting (1 0.5 MAC; $11 \mathrm{MAC}$; E 0.5 MAC; E $1 \mathrm{MAC}$ ). Blood samples for PRA, plasma $E, N E$ and aldosterone determination were collected at the time of the haemodynamic measurements in the eight patients of the isoflurane group. In patients without neurologic disease, nitrous axide and the inhalation agents were discontinucd following the manoeuvre of spinal distraction to allow intraoperative awakening to test the patient's ability to move the lower extremities. Thiopentone and the halogenated agent were then used to restore anaesthesia, after a satisfactory response was obtained to the vocal command, "move your feet."

Group means are presented with the standard deviation as the index of dispersion. Student's I test for paired data was used to analyze the dihydralazine effects. A $p$ value $<0.05$ was considered significant. A two-way analysis of variance (group and stage) was used to analyze the halogenated agent effects. After a significant $F-$ statistic $(p<0.05)$, Student's $t$ tests for paired (within group analysis) and unpaired data (between group analysis) with the Bonferroni correction were used to localize the differences. Statistical analysis of the hormonal values were done after logarithmic transformation of the data.

\section{Results}

The study group characteristics are shown in Table I. Baseline haemodynamic values were similar in the two groups. Urinary output was absent during the period of hypotension and returned to normal $\left(\geq 1.0 \mathrm{ml} \cdot \mathrm{kg}^{-1} \cdot \mathrm{hr}^{-1}\right.$ ) following restoration of arterial blood pressure. No hypertensive rebound was observed on intraoperative awakening or in the postoperative period. No neurological complications were observed intra or postoperatively.

The effects of dihydralazine are summarized in Table II. Stable hypotension was achieved in all patients $(\mathrm{N}=16)$ $20 \mathrm{~min}$ after the first dihydralazine IV injection. The decrease in MAP reached 20 per cent. Cardiac index increased significantly by 57 per cent, mainly due to an increase in HR (+37 per cent) while PCWP was unaffected. Intrapulmonary shunt increased significantly, with an increase in mixed venous oxygen content while arterial oxygen content remained unchanged. Epinephrine plasma concentration remained stable and below the upper limit of normal values, but PRA, NE and aldosterone plasma concentrations increased significantly (Figure).

The effects of the addition of the inhalation agents are 
TABLE III Results: Hydralazine-enflurane hypotension $(n=8$; mean \pm SD $)$

\begin{tabular}{|c|c|c|c|c|}
\hline & $\begin{array}{l}20 \text { min after } \\
\text { IV dihydralazine }\end{array}$ & $\begin{array}{l}\text { Enflurane } \\
0.5 \mathrm{MAC}\end{array}$ & $\begin{array}{l}\text { Enflurane } \\
I M A C\end{array}$ & ANOVA \\
\hline $\mathrm{MAP}(\mathrm{mmHg})$ & $76 \pm 9$ & $67 \pm 5^{\dagger}$ & $61 \pm 5 t \div$ & $<0.001$ \\
\hline HR (beat $\cdot \mathrm{min}^{-1}$ ) & $115 \pm 11$ & $120=11$ & $114 \pm 8$ & NS \\
\hline RAP (mInHg) & $6.7 \pm 2.7$ & $6.5 \pm 2.8$ & $6.0 \pm 2.4$ & NS \\
\hline MPAP (mmHg) & $17.2 \pm 4.7$ & $16.2 \pm 4.4$ & $16.2 \pm 3.4$ & NS \\
\hline PCWP (mmHg) & $8.7 \pm 3.6$ & $8.1 \pm 3.8$ & $7.8 \pm 3$ & NS \\
\hline$C I\left(L \cdot \min ^{-1} \cdot m^{-2}\right)$ & $5.5 \pm 1$ & $5.4 \pm 0.9$ & $5.0 \pm 0.6$ & NS \\
\hline SI $\left(\mathrm{ml}^{\prime}\right.$ beat $\left.^{-1} \cdot \mathrm{m}^{-2}\right)$ & $48 \pm 7$ & $45 \pm 6$ & $44 \pm 7$ & NS \\
\hline SVRI $\left(d y n \cdot s \cdot \mathrm{cm}^{-5} \cdot \mathrm{m}^{-\bar{z}}\right)$ & $995 \pm 150$ & $880 \pm 170^{*}$ & $880 \pm 130 *$ & $<0.05$ \\
\hline $\mathrm{Hb}\left(\mathrm{g} \cdot \mathrm{dl}^{-1}\right)$ & $11.2 \pm 0.6$ & $10.7 \pm 1.4$ & $10.5 \pm 1.2$ & NS \\
\hline$Q s / Q t(\%)$ & $13.5 \pm 7.5$ & $13.8 \pm 4.5$ & $13 \pm 5.2$ & NS \\
\hline $\mathrm{VO}_{2} \mathrm{I}\left(\mathrm{ml} \mathrm{O} \mathrm{O}_{2} \cdot \mathrm{min}^{-1} \cdot \mathrm{m}^{-2}\right)$ & $121 \pm 23$ & $120 \pm 26$ & $115 \pm 25$ & NS \\
\hline
\end{tabular}

ys 20 min after IV dihydralazine * $p<0.05 \dagger p<0.01$

vs enflurane 0.5 MAC $\neq \mathrm{p}<0.001$.

summarized in Tables III and IV. With 0.5 MAC anaes thetic levels, further decreases in MAP and in SVRI were abserved in both groups. With 1.0 MAC levels a further decrease in MAP was observed in both groups but the decrease was greater in the isoflurane group than in the enflurane group (eight per cent with enflurane and 17 per cent with isoflurane) ( $p<0.01$ ). A further decrease in SVRI ( 13 per cent) was observed only in the isoflurane group. PRA, E and NE plasma concentrations remained unchanged while aldosterone increased $(\mathrm{p}<0.02)$ when 0.5 and 1.0 MAC levels of isoflurane were added (Table V).

\section{Discussion}

Dihydralazine and hydralazine are two commercially available hydrazinophtalazines with very similar pharmacological effects. ${ }^{15}$ Previously, hydralazinc was used during anaesthesia with enflurane. ${ }^{5}$ Intravenous injections of hydralazine 5 to $10 \mathrm{mg}$ given every $5 \mathrm{~min}$ ( 5 to 45 ing) induced hypotension to a MAP between 55-65 mrifg for 5-87 min, for neurosurgery aneurysm clipping. However, the effects of hydralazine and enflurane were not examined separately.

The actions of hydralazine or dihydralazine on the cardiovascular system are partly due to direct drug effect and partly to reflex response. The primary action is the direct reliaxition of the vascular smooth muscle, with subsequent blood pressure (diastolic and systolic) and peripheral resistance fall. ${ }^{16,17} \mathrm{~A}$ direct relation between plasma hydralazinc concentrations and hypotension exists in the hypertensive patient ${ }^{18,19^{\circ}}$ The choice of a "high" initial dose $\left(1.0 \mathrm{mg} \cdot \mathrm{kg}^{-\mathrm{L}}\right)$ in our study was determined by a preliminary study (unpublished data); during narcotic anaesthesia without halogenated volatile agent, doses of dihydralazine less than $1.0 \mathrm{mg} \cdot \mathrm{kg}^{-1}$ led to modest or absent falls in systolic blood pressure. In our study the desired level of hypotension for this non-neurological procedure ${ }^{4}$ was not reached. MAP did not fall to levels

TABLE IV Results: dihydralazine-isoflurane hypotension $(n=8$; mean \pm SD)

\begin{tabular}{|c|c|c|c|c|}
\hline & $\begin{array}{l}20 \text { min after } \\
\text { IV dihydralazine }\end{array}$ & $\begin{array}{l}\text { Isofiurane } \\
\text { O.5 MAC }\end{array}$ & $\begin{array}{l}\text { Isoflurane } \\
\text { I MAC }\end{array}$ & $A N O V A$ \\
\hline MAP (mmHg) & $76 \pm 8$ & $62 \pm 9 \dagger$ & $52 \pm 3+\S$ & $<0.001$ \\
\hline HR (beat min $^{-1}$ ) & $122 \pm 9$ & $123 \pm 10$ & $118 \pm 10$ & NS \\
\hline $\mathrm{RAP}(\mathrm{mmHg})$ & $6.7 \pm 3.2$ & $6.9 \pm 3$ & $7.0 \pm 2.6$ & NS \\
\hline MPAP $\left(\mathrm{mmH}_{\mathrm{g}}\right)$ & $17.3 \pm 4.8$ & $16.6 \pm 3.8$ & $17.1=3.3$ & NS \\
\hline PCWP (mmHg) & $8.7 \pm 3.8$ & $9.3 \pm 2.4$ & $9.3 \pm 2.2$ & NS \\
\hline $\mathrm{Cl}\left(\mathrm{L} \cdot \mathrm{min}^{-1} \cdot \mathrm{m}^{-2}\right)$ & $5.50 \pm 1.10$ & $5.10 \pm 1.00$ & $4.75=0.80$ & NS \\
\hline $\mathrm{SI}\left(\mathrm{ml} \cdot \mathrm{bcat}^{-1} \cdot \mathrm{m}^{-2}\right)$ & $45 \pm 9$ & $41 \pm 9$ & $40 \pm 8$ & NS \\
\hline SVRT $\left(\right.$ dyn $\left.\cdot 5 \cdot \mathrm{cm}^{-5} \cdot \mathrm{m}^{-2}\right)$ & $995 \pm 180$ & $860 \pm 190^{*}$ & $750 \pm 150^{* 1+}$ & $<0.01$ \\
\hline $\mathrm{Hb}\left(\mathrm{g} \cdot \mathrm{dl}^{-1}\right)$ & $11.1 \pm 1.2$ & $10.5=1.4$ & $10.8 \pm 1$ & NS \\
\hline $\mathrm{Qs} / \mathrm{Qt}(\%)$ & $13.9 \pm 8.3$ & $14.0 \pm 6.0$ & $12.0 \pm 4.0$ & NS \\
\hline $\mathrm{VO}_{2} \mathrm{I}\left(\mathrm{ml} \mathrm{O} \mathrm{O}_{2} \cdot \mathrm{min}^{-1} \cdot \mathrm{m}^{-2}\right)$ & $115 \pm 19$ & $105 \pm 28$ & $104 \pm 25$ & NS \\
\hline
\end{tabular}

$v_{s} 20$ min aficr $I V$ dihydralazine $* p<0.05 \dagger p<0.001$

$v s$ isothrane $0.5 \mathrm{MAC} \neq \mathrm{p}<0.0 \mathrm{~J} \$ \mathrm{p}<0.001$. 
TABLE V Plasma concentrations of renin, aldosterone and catecholamincs during dihydralazine-isoflurane hypotension (mean (range))

\begin{tabular}{lllll}
\hline & $\begin{array}{l}20 \text { min after } \\
\text { IV dihydralazine }\end{array}$ & $\begin{array}{l}\text { Isofurane } \\
0.5 \text { MAC }\end{array}$ & $\begin{array}{l}\text { Isofturame } \\
\text { I MAC }\end{array}$ & ANOVA \\
\hline $\begin{array}{c}\text { PFA } \\
\left(\mathrm{ng} \cdot \mathrm{ml}^{-1} \cdot \mathrm{hr}^{-1}\right)\end{array}$ & $30(21-48)$ & $34.5(21-47)$ & $34.8(26-48)$ & NS \\
$\begin{array}{c}\text { Plasma aldosterone } \\
\left(\mathrm{ng} \cdot \mathrm{dl}^{-1}\right)\end{array}$ & $13.8(5.2-29.8)$ & $18.5(8.3-43)^{*}$ & $24.7(16-46)^{*}$ & $<0.02$ \\
$\begin{array}{c}\text { Plasma norepinephrine } \\
\left(\text { (nmol } \cdot \mathrm{L}^{-1}\right)\end{array}$ & $3.8(2-6.8)$ & $3.9(2.1-6.7)$ & $3.9(1.95-7.1)$ & NS \\
$\begin{array}{c}\text { Plasma epinephrine } \\
\left.\text { (nmol. } \mathrm{L}^{-1}\right)\end{array}$ & $0.25(0.17-0.35)$ & $0.30(0.19-0.38)$ & $0.31(0.18-0.38)$ & NS \\
\hline
\end{tabular}

${ }^{*} \mathrm{p}<0.02$ vs 20 min after IV dihydralazine.

below $60 \mathrm{mmHg}$ in any patient. Therefore the risk of dihydralazine producing excessive hypotension during narcotic anaesthesia is low in euvolemic and normotensive subjects with normal left ventricular function. The vasodilatory effects of dihydralazine, limited to the arteriolar bed without reduction of preload, produced a rise in $\mathrm{CO}$, mainly by tachycardia and by an increase in SV. This unchanged preload offers several advantages over other vasodilating drugs in noncardiac patients. The response to the venous pooling and arterial-dilating effects of nitroprusside or nitroglycerin may be a reduction in cardiac output. ${ }^{20,21}$ Under these circumstances, fluid loading is needed to maintain $\mathrm{CO}^{22}$ Dihydralazine avoids this fluid supplementation requirement. The dose-dependent tachycardia ${ }^{23}$ could be deleterious in the setting of ischaemic heart disease, ${ }^{24}$ particularly as diastolic blood pressure and coronary perfusion pressure were decreased, so that older patients with aneriosclerotic heart disease may be at risk of myocardial ischaemic events. No deleterious metabolic effects were observed. On the other hand, the increase in CO was coupled with an increase in intrapulmonary shunt. However, in contrast with the other vasodilators, ${ }^{25}$ hydralazine increased mixed venous oxygen content and did not decrease arterial oxygen content. ${ }^{26}$

Our study demonstrated that when dihydralazine was given to young normotensive patients in doses that lower MAP by $15-30 \mathrm{mmHg}$, the patients respond with a four-fold increase in PRA and a 1.5-fold increase in plasma NE. Previously, Pettinger et al. found that hydralazine (1.0 $\mathrm{mg} \cdot \mathrm{kg}^{-1}$ ) elicits an increase in PRA in animals. The peak increase (five-fold) occurs at $20 \mathrm{~min}$ and renin activity remained elevated for the next five hours. ${ }^{27}$ This stimulation of renin release is due both to a fall in renal perfusion as a result of the fall in MAP, and to an increase in activity of the peripheral sympathetic nervous system. In addition, the fall in renal perfusion pressure which results from the decrease in systemic blood pressure, may serve to potentiate the renin-releasing effects of the reflex incrcase in noradrenergic activity at the granular juxtaglomerular cells. ${ }^{28}$ Furthermore, increased PRA generates additional angiotensin which stimulates catecholamine release, and in furn stimulates additional renin release. ${ }^{28,29}$ However, there is a greater increase in NE relative to a fall in MAP with nitroprusside than with hydralazine. ${ }^{30}$ Finally, this release of vasoactive agents and the increased sympathetic activity act as a defense against hypotension: angiotensin and NE minimize arteriolar vasodilation and catecholamines increase heart rate and cardiac output. ${ }^{30}$

As reported by James and Bedford, enflurane was an integral part of the combined technique (hydralazine + enflurane) used for achieving controlled hypotension. ${ }^{5}$ Furthermore, in our study halogenated supplementation was necessary even if high doses of dihydrakazine were administered, because blood pressure did not decrease enough without inhalational supplementation. Our interest has focused on isofiurane, in comparison with enflurane, since recovery has been reported to be equally rapid after isoflurane and enflurane anaesthesia ${ }^{31}$ or more rapid ${ }^{32}$ with isoflurane anaesthesia, particularly after prolonged anaesthesia. These agents may decrease arterial pressure by different underlying mechanisms. Isoflurane reduces systemic vascular resistance more than contractility, in contrast with enflurane which reduces cardiac output. ${ }^{31}$ In our study the addition of either halogenated volatile agent led to a further decrease in blood pressure by decrease in SVRI. However, the effect of enflurane and isoflurane at $0.5 \mathrm{MAC}$ was not significantly different, whereas at 1.0 MAC the vasodilation and hypotensive effects of isoflurane were greater than those of enflurane. These results emphasize the intensity of the vasodilatory effect of isoflurane which remained despite the preliminary vasodilatation produced by dihydralazine and the release of vasoactive agents. In both groups sustained hypotension for three hours did not induce myocardial ischaemia metabolic disorders. In James and Bedford's study MAP 
returned to baseline values in $20.8 \pm 5.7 \mathrm{~min} .^{5}$ In our study, the mean duration of scoliosis surgery was $235 \pm$ $46 \mathrm{~min}$ and MAP returned to baseline values in $6 \pm 2.8$ min after the halogenated agent was stopped, in spite of the first dose of $1.0 \mathrm{mg} \cdot \mathrm{kg}^{-1}$ of dihydralazine, and supplementary doses of $0.25 \mathrm{mg} \cdot \mathrm{kg}^{-1} 1.30$ to 2 hours later. Sustained beta-adrenergic stimulation induced by dihydralazine and moderate concentration of inhalation agents ( 0.5 or $1.0 \mathrm{MAC}$ ) may explain the absence of a significant decrease in $\mathrm{CO}$, despite the known negative inotropic effects of both agents. The other haemodynamic effects (tachycardia, pulmonary vasodilation and shunt fraction increase) related to dihydralazine remained unmodified when enflurane or isoflurane were added to dihydralazine as well as the neuroendocrine effects (releases of angiotensin and norepinephrine) when isoflurane was added to dihydralazine.

In summary, the combination of dihydralazine with enflurane or isoflurane is an effective technique for controlled hypotension during scoliosis surgery. The reduction in arterial blood pressure to a level of 50-60 $\mathrm{mmHg}$ for three to four hours was free of complications. The preliminary IV administration of dihydralazine allowed the halogenated anaesthetic agent concentrations to be reduced, which attenuated the undesirable effects of the volatile agents and facilitated intraoperative awakening. However, dihydralazine produced sympathetic and renin-angiotensin-aldosterone axis stimulation. The precise level of hypotension is easy to control by adjustment of the concentration of the inhalation agent.

\section{Acknowledgments}

The authors are grateful to Ciba Geigy Laboratories for providing dihydralazine. We also thank Dr. Marie-France Ganansia for preparation of this manuscript.

\section{References}

I Khambatta HJ, Stone JG, Matteo RB, Michelsen WJ. Hypotensive anesthesia for spinal fusion with sodium nitroprusside. Spine 1978; 3: 171-6.

2 Kafer ER. Respiratory and cardiovascular functions in scoliosis and the principles of anesthetic management. Anesthesiology 1980; 52: 339-51.

3 Malcolm-Smith NA, McMaster MJ. The use of induced hypotension to control bleeding during posterior fusion for scaliosis. J. Bone Joint Surg (Br) 1983; 65: 255-8.

4 Lam AM. Induced hypotension. Can Anaesth Soc J 1984; 31: $\$ 56-\$ 62$.

5 James DJ, Bedford RF. Hydralazine for controlled hypotension during neurosurgical operations. Anesth Analg 1982; 61: 1016-9.

6 Black GW. Enflurane. Br J Anaesth 1979; 51; 627-37.
7 Abott $T R$, Bentley $G$. Intraoperative awakening during scoliasis surgery. Anaesthesia 1980; 35: 289-302.

8 Dorgan JC, Abott TR, Bentley $G$. Intraoperative awakening to monitor spinal cord function during scoliosis surgery. J Bone Joint Surg (Br) 1984; 66: 716-9.

9 Eger EIN. The pharmacology of isoflurane. Br J Anaesth 1984; 56: 71S-99S.

$10 \mathrm{Hug} \mathrm{CC} \mathrm{Jr}$. Monitoring. In: Miller RD (Ed,). Anesthesia Second Edition. New York: Churchill Livingstone Inc. 1986: 411-63.

11 Haber E. Koerner T, Page LB, Kimura B, Purnode A. Application of radioimmunoassay for angiotensin I to the physiologic measurements of plasma renin activity in normal buman subjects. J Clin Endecrinol 1969; 29: 1349-55.

12 Mayes D, Furuyama S, Kem DC, Nagem CA. Radioimmunoassay for plasma aldosterone. J Clin Endocrinal 1970; 30: 682-5.

13 Brown MJ, Jenner DA. Novel double-isotope technique for enzymatic assay of catecholamines, permitting high precision, sensitivity and plasma sample capacity. Clin Sci 1981; 61: 591-8.

14 Trunet P. Lhoste F, Ansquer JC et al. Decreased plasma epinephrine concentrations after glucose ingsstion in bumans. Metabolism 1984; 33: 101-3.

15 Struyker-Boudier HAJ, Van Essen H, Smits JFM, Hemodynamic cffects of the arteriolar vasodilator hydralazine, dihydralazine and endralazine in the conscious spontaneously hypertensive rat. Eur J Pharmacol 1983,95: $|5|-9$.

16 Koch-Weser J. Hydralazine. N Engl J Med 1976, 295 : 320-3.

17 Khatri I, Vemura O, Notargiacomo A, Freis ED. Direct and reflex cardiostimulating effects of hydralazine. Am J Cardiol 1977; 40: 38-42.

18 Zacest $R$, Koch-Weser $J$. Relation of hydralazine plasma concentrations to dosage and hypotensive action. Clin Pharmacol Ther 1972; 13: 420-5.

19 Ludden TM, Shepherd AM, MCNay JL, Lin MS. Effects of intravenuus dose on hydralazine kinetics after administration. Clin Pharmacol Ther 1983; 34: 148-52.

20 Gerson $J I$, Allen FB, Seitzer JL, Parker FB, Markowitz $A H$. Arterial and venous dilatation by nitroprusside and nitroglycerin. Is there a difference? Anesth Analg 1982; 61 ; 256-60.

21 Brent BN, Berger HJ, Matthay RA, Mahler D. Pytlik L, Zaret $B L$. Contrasting acute effects of vasodilators (nitroglycerin, nitroprusside, and hydralazine) on right ventricular performance in paticnts with chronic obstructive pulmonary disense and pulmonary hypertension: A combined radionuclide-hemodynamic study. Am I Cardiol 1983: 51: 1682-9. 
22 Cohn $J N$, Franciosa JA. Vasodilator therapy of cardiac failure (first of two parts). N Engl J Med 1977; 297: $27-31$.

23 Stern HC, Matthews HJ, Belz GG. Influence of dihydralazine induced afterload reduction on systolic time intervals and echocardiographic in healthy subjects. Br Heart J 1984; 52: 435-9.

24 Magorien RD, Brown GP, Underferth DV et al. Effects of hydralazine on coronary blood flow and myocardial energetics in congestion heart failure. Circulation 1982; 65: 528-33.

25 Casthely PA, Lear S, Courell JE, Lear E. Intrapulmonary shunting during induced bypotension. Anesth Analg 1982; 61: 231-5.

26 Sandoval J, Lopez $R$, Beltran $U$ et al. Effect of hydralazine on intrapulmonary shunt. Crit Care Med 1986; 14: 689-92.

27 Pettinger WA Campbell WB, Keeton $K$. Adrenergic component of renin release induced by vasodilating antihypertensive drugs in the rat. Cir Res 1973; 33: 82-6.

28 Peach MJ. Renin-angiotensin system: biochemistry and mechanisms of action. Physiol Rev 1977; 57: 313-70.

29 Pettinger WA. Ancsthetics and the renin-angiotensinaldosterone axis. Anesthesiology $1978 ; 48: 393-6$

30 Lin MS, McNay $J$, Shepherd AM, Keeton TK. Effects of hydralazine and nitroprusside on plasma catecholamines and heart rate. Clin Pharmaçol Ther 1983; 34: 474-80.

31 Jones $R M$. Clinical comparison of inhalation anaesthetic agents. Br J Anaesth 1984; 56: 575-69S.

32 Kortila $K$. Valanne $J$. Recovery after outpatient isoflurane and enflurane anesthesia. Anesth Analg 1985; 64: 239.

\section{Résumé}

La réponse hémodynamique et neuroendocrinienne à l'injection intraveineuse de dihydralazine $\left(1.0 \mathrm{mg} \cdot \mathrm{kg}^{-1}\right)$ suivie de ladministration d'enflurane ou d'isoflurane (0.5 puis $1.0 \mathrm{MAC})$ a été étudiêe chez 16 patients âgés de 13 a 38 ans subissant une correction chirurgicale de scoliose sous hypotension contrôlee. Vingt minutes aprés l'injection de dihydralazine, la pression artérielle moyenne et les résistances vasculaires systémiquess se sont abaisśées (-20 et -50 pour cent respectivement) ei l' index cardiaque et la fréquence cardiaque se sont ólevés (+57 et +37 pour cent respectivemeni) de même que te shunt intrapulmonaire. Une diminution supplémentaire de la pression artérielle moyenne et des résistances vasculaires systémiques a été observée après introduction d' enflurane ou d'isoflurane a MAC 0.5. L'augmentation de la concentration alvéolaire da MAC 1.O a majoré la baisse de pression artérielle dans les deux groupes, mais le niveau de pression atteint a été plus bas avec l'isoflurane qu'avec l'enflurane $(p<0.01)$. La reduction de pression artérielle moyenne à un niveau de 50 à $60 \mathrm{mmHg}$ a été facile à contróler pendant trois à quatre heures et n'a pas entrainé de complication. L'administration intraveineuse préalable de dihydralazine permet la réduction des concentrations alvéolaires des agents anesthésiques volatils ce qui atténue leurs effets hêmodynamiques indésirables en dépit d' une libération de rénine et de noradrénaline, et donc facilite un réveil peroperatoire rapide. 